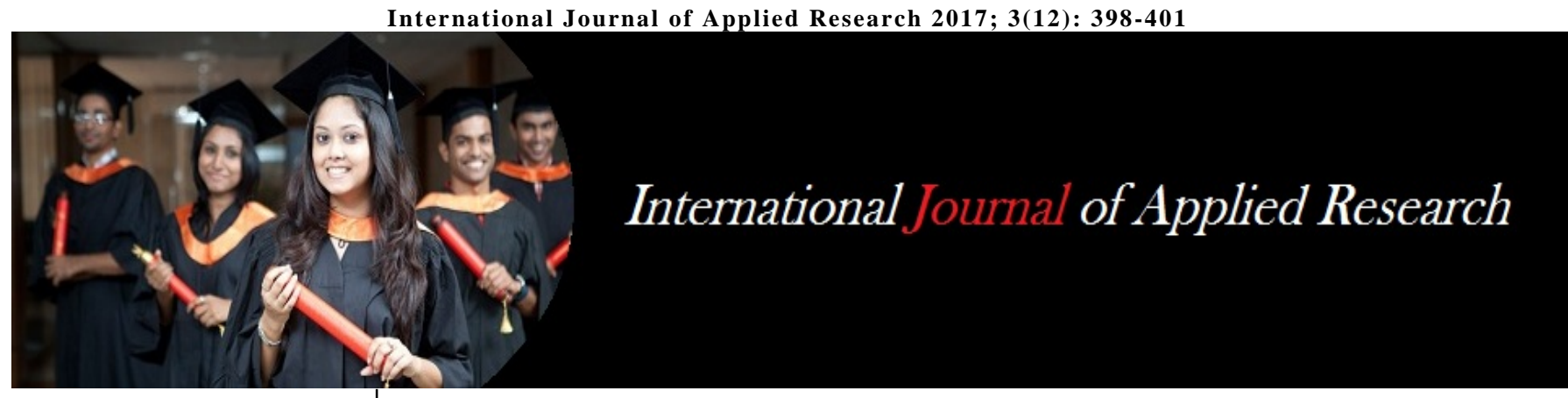

ISSN Print: 2394-7500

ISSN Online: 2394-5869

Impact Factor: 5.2

IJAR 2017; 3(12): 398-401

www.allresearchjournal.com

Received: 09-10-2017

Accepted: 10-11-2017

Gopal Chandra Hembram

Assistant Professor,

Department of Geography,

Haldia Government College,

Debhog, Purba-Medinipur,

West Bengal, India
Correspondence

Gopal Chandra Hembram

Assistant Professor,

Department of Geography,

Haldia Government College,

Debhog, Purba-Medinipur,

West Bengal, India

\section{Validitating the role of education and skill-based training in empowerment of Bengali women}

\section{Gopal Chandra Hembram}

\author{
DOI: https://doi.org/10.22271/allresearch.2017.v3.i12f.9496
}

\section{Abstract}

Education and skill-based training play a vital role for women empowerment, prosperity, development and welfare. In every stages of history there were challenges upon women. Discrimination of women from womb to tomb is unanimously true. Unending inequality and vulnerability of women in everywhere and women oppressed in all spheres of life, they need to be empowered in all stages of life. In order to stand, protest and fight against the socio-culturally constructed gender biases, women have to swim against the system that requires more mental strength and power. Such strength, elegancy comes from the process of empowerment and empowerment will come from the education and skillbased Training. And in true sense rural development will come from women empowerment. This paper is trying to analyse and justify the empowerment of women via education and skill-based training and identifying the impact of education and Training in women overall empowerment in Purba Medinipur district, W.B., India. Totally 49\% women respondents between $20-50$ age group were selected for the study. Outcomes of the study shows that educational qualification and training play significant role in women empowerment and it concludes that if women's empowerment is to be effected, it can be carried out only through the medium of education and training. Hence, it is of foremost importance to raise the level of education and skill-based training amongst women.

Keywords: Role of education, skill-based training, women empowerment, women literacy

\section{Introduction}

Education is remarkable parameter/sole parameter of women empowerment as because it enables them to responds to the challenges to confront their socially conventional/traditional role and mould up their hectic life. Now just some year away, this can become reality only when the women of this nation became empowerment. Education enables a women to become strong physically by giving her knowledge about good physical health, which would ultimately benefit her mental health Agrawal and Salve (2013) ${ }^{[1]}$. Each and every field such as teaching, Nursing care, Social work, medicine, Women proved to be better than men. Women's power is crucial/significant to economic, educational, family, spiritual moral and aesthetic growth. Education, functional literacy and skill-based training empowers women. The only way a family, society or aspire to economic growth and development is to just through education but especially education among the women's citizens. Education is considered as a primary requirement and a fundamental right for the citizens of any nation. It is a powerful tool for reducing inequality as it can give people the ability to become independent. Women, who come across discrimination in any spheres, have particular needs of this. Education is regarded as an important millstone of women empowerment because it enables them to face the challenges, to confront their traditional role and change their life. Education of women is the most important tool of change their position in the society. Still large women folk of our country are literate, backward, weak and exploited Alva and Hans $(2013)^{[2]}$.

\section{Database and methodology}

The present article is exclusively based on:

1. Primary data-Field survey

2. 2. Secondary data-I. Books, II. Journals, III. Report provided by the Government Offices, IV. Others. 
3. Provisional population totals of the district of PurbaMedinipur, W.B., Census of India 2011.

The primary data which have been collected through the sample survey, for selecting the sample word for household survey in Durgachawk stratified random sampling has been used.

This paper discussed different types /means of inequalities of women in durgachawk, W.B., India. And side by side also depict the goals of skill-based literacy programme of women.

\section{Discussion}

\section{Concept of Empowerment}

- The process of acquiring, providing, bestowing the resources is in general known as empowerment. The way or enabling the access to and control over such means and resources is also part of that empowerment. Thus, the potentiality to gain power upon owns desire or that another party could make it possible to have power. This is crucial in terms of identify and pick up the potential agents of empowerment. It is the person who is to be empowered or it could be another person or agent. The processes of self-development and selfpropelling can be termed as empowerment. Gift of God dawns on any women and which may change her life more developed and more uplifted. Even though she tried to act upon such thoughts, linked up with the source of resources, she is facilitating her own empowerment

- Empowerment means the ability of person to acquire thought or knowledge and have an idea or perception of what is awkward, unsuitable and unfavorable about her present condition, perceive a better situation, the possibilities of attaining it and realizing what is within her reach and what she could do to get to a better situation. This type of features of empowerment applicable when the mechanism could modify the selfperceptions or the environment, and the communion involved in between her-self and environment. It is a developing procedure of something new, alternative images, that she motivates herself or triggers present generation to do something new, better and sustainable one or what psychologists call motivation. Perception change means the change of mind-set towards her daily life and nourishment.

- Empowerment makes woman capable of being creative and productive one and as a result of having such creative or productive power, she earns leverage and bidding power. Empowered, a woman would take steps to find and/or create options or find and link to the means to find the options. Person's choice and demand could be controlled by the stages and degree of Empowerment. It is able to generate the person's choosing ability towards her goals, create good possibilities to reach the goals and determine the overall direction of her life. This is why the concept of empowerment is fascinating and powerful one. In the Third World, some women's have no choices to their own life goals and this lack of choice makes them ultimately powerless.

- In gist through woman empowerment she is able to develop herself a comparatively strong woman in terms of productive power and bargaining power. Secondly, she could be able to reduction of men-centric demand, choices and enables to draw attention from those concerned, particularly decision and policy makers, to generate the appropriate positive responses, reduction of vulnerability, reduction or elimination of exploitability, availability and use of social services and resources. Ultimately, empowerment should lead to the improvement of women's socio-economic status.

Definitions of empowerment may vary but Paz is most insightful - it is "the ability to direct and control one's own life" (Paz, 1990). The report of the 1991 Seminar on the integration of women in development elaborates that it is a "process in which women gain control over their own lives of knowing and claiming their rights at all levels of society at the international, local and household levels. Selfempowerment means that women gain autonomy, are able to set their own agenda and are fully involved in economic, political and social decision-making processes" (Depthnews, 1992).

\section{Vital elements of skill-based Training}

Gender Issues and its long term values concerned with the roles of women and men. It is an outcomes of the traditional view: areas of work assigned to men and women; distribution of access to resources and their control; access to and respective ways of earning and spending.

Gender issues are deal with sincerely from very beginning, their involvement in questioning is completely depends own attitudes, values and beliefs, frequently the very essence of one's existence. Activities are preplanned in manner and this planned execute precociously to ensure that all opinions are respected. In this way, participants become open to reconsidering their values.

The nature of activities and introduce of this joyful activities also plays an important role in generating a nonoverburdening climate. In a skill-based training all time questions from peers also help participants entertain new views without feeling pressured into accepting them.

There are more varied, interesting thought provoking and appealing training materials than usual as they are to induce new attitudes. The methods of training are Audio-visuals methods and these are most effective because they present the cases in which participants recognize their shortcomings without being directly challenged.

On the other interesting exercise, such as drawing and the Agree/Disagree game, lead groups to reflect on their beliefs, are fun, and reveal a lot without hazitating anyone. Peer pressure is another means to cause an individual to reexamine her ways, consider new options, and adopt or reject them.

Groups have come up with exercise models that intensify the scrutiny of gender issues by assigning a framework of action. In one case they suggest assigning their future learners to write short dialogues for well-known male and female cartoon characters caught in expressive scenes of conflict, debate, or reconciliation.

\section{Productive Education and Skills}

Education towered thoughts, thinking power, analytical mind, imagination power, principles of various stages of life for ease livelihood and extract knowledge through education. Educated women able to brings high level of equal living status and living opportunities and create stress 
free environment to develop herself that means equipping women which makes her self-suffucient in every aspect and stages of life.

Education opens the ways of make versatile decision and choose according to their own choice that relates life, life partner, job-career, clothing-eating styles, sexuality and so on.

Education tuned, expertise women to overcome all sorts of crime, sexual and mental torture in and outside of society etc.

Qualified women are always her family by means to earn money, thus she able to develop the economic status of family and also for nation. "Women can help, through their work; get rid of problems like India's high maternal mortality rate, high rates of gender violence and other crime against women child sex abuse, female feticide, implement family planning and other schemes etc”. Sharma (2016) ${ }^{[4]}$.

\section{Women empowerment via education and training}

In all time, all situation and all $3^{\text {rd }}$ world countries women are failure to give hundred of hundred to the nations for the purpose of development. The skill-based training help prepare women for self-development as active productive members of their family, community and nation. They seek overall personal development and account for the notorious double responsibility that women shoulder as economic producers and as mothers and wives. The above age old social systems imparting thought, knowledge, skills, analytical power and attitudes that help women operate as efficient and equal partners of men. It is important to stress collaboration between the sexes and to make sure that empowerment does not mean "pitting women against men". The new concept on the learning arena include planning, management and entrepreneurial habits. Fruitful basic education and productive skill-based training may helpful unanimously men or women in any work area. Building up positive self-image and strengthening of women's selfconfidence also receives due attention.

\section{The Profile of the Empowered Woman}

The empowered woman appreciates the time she spends on domestic work and outside the home. She is aware that overwork is harmful to her physical and mental condition and that health is vital. She is able to question her double responsibility and seeks help from others to have enough leisure to spend on learning and participating in the social and political life of the community.

The empowered woman appreciates the value of her contribution whether remunerated or not. She is aware that she has tremendous potential to contribute to the progress of her family, community and nation. With that understanding, she is confident of her worth, is open-minded and can appreciate others.

Aware of her productivity, she seeks to improve her skills and knowledge continuously. She has enough information sources (such as extension services, available and relevant technology) and makes sure she benefits from them. She appreciates the knowledge gained from reading and reads regularly.

The empowered woman understands that she is a human being and can control her own life. Hence, she could and should question the family and social practices which negatively affect her. She seeks to get scientific insights into superstitions, and challenges those which are unjust to women. She has freedom of movement and expression on a par with men. She appreciates her strengths and weaknesses and seeks self-improvement. She can lead and serve as a positive role model for other women. The empowered woman is aware of her rights as a citizen and protects them actively. She is convinced of her equality with men. She knows which laws and legal processes treat women unfairly and seeks to use her legal knowledge to protect her own and other women's rights.

The empowered woman respects herself and dares take credit and responsibility for her contribution and action. She looks for options and makes informed decisions. She dares to be different and creative. The empowered woman appreciates and supports other women. She is aware that organization means strength and seeks to strengthen her organizational, management and leadership skills.

The empowered woman is aware that her health is related to the number of children she has. She respects the dignity of womanhood and appreciates daughters in the same way she does sons. The empowered woman nurtures herself. She wants everybody to understand that, as a human being, she is entitled to happiness in the same way that others are. She has a zest for life. The training manual, Educate to Empower attempts to translate one or more of the above desirable attributes into learning content of the curricular units or reading materials. Content Presentation The debate on the desirable qualities of the empowered woman centers on competence, proficiency and behavior attributes. It also spells out an implicit scenario in which the woman sheds the yoke of the numerous social, cultural and economic roles. It is possible that in a few countries, a small number of women may possess these qualities. However, these women remain a small minority in any country - - so widespread, crossnationally, are the constraints to emancipation. Educate to Empower attaches equal importance to the productive and reproductive functions of the woman. Emphasis on one to the exclusion of the other either prevents women from being economically active or saddles them with additional and burdensome responsibilities. Programmes developers must ensure that the contents of a programme help women raise their awareness regarding their conditions and question the asymmetrical relations within the household and society. In the final analysis, all the knowledge, skills or attitudes promoted by a programme must be useful in providing learners with knowledge, skills and attitudes which equip them to take actions for changes which will improve their status in society and lead to their emancipation. Monitoring and Evaluation Monitoring is done informally. Visits to focal point and target populations offer better insights into the project realities and give an idea of improvements required and lessons learned. Informal discussion and contact with life in target areas along with the analysis of curricular materials, help make them realistic 56 and relevant. This reflects the quality of the national training which, in turn, echoes the degree of effectiveness of the regional training.

\section{Empowerment and Policy Makers}

The term empowerment has been a nonstarter in India. Many so-called traditional societies have been vehemently negative towards any programmes or projects claiming to focus on the empowerment approach (Ramachandran 1985). The term is interpreted to have militant overtones akin to "pitting women against men". It has evoked a great deal of 
antagonistic feelings among policy makers seeing this as a threat to the stability of the family institution or even the human race.

Somewhere, somehow, something went wrong. Policy makers, most of whom are men, have distanced themselves from even considering the concept. Their assumption: there cannot be empowerment of women without disempowerment of men. Some have explicity expressed concerns over men's potential loss of "control" over their wives and daughters. Others fear, genuinely, that they will not be able to respond to new demands arising from empowerment education.

Even when policy makers - indeed men in general, are supportive of the empowerment concept, their support remains largely intellectual. They do not deem it necessary to insist on actions leading to positive changes. This may be compared to what happens in many domestic situations. The husband recognizes that strictures on women are unfair. He cannot, however, give up any of the foothold he has acquired in his job or any of his pay in order to share responsibility for the children.

The question facing policy makers, with traditional values regarding the roles of women and men in society, is whether such changes are desirable and worthy of support. Thus far, advocates of Education for Empowerment have failed to convince policy makers to see the value of embracing women's empowerment as one of the necessary prerequisites for advancing society. Arguably, when one examines the situation of women's education in Asia and the Pacific, it could be said that no country in the region has made substantial progress in promoting women's empowerment.

One thing is clear, empowerment education will not make a difference in women's status on a large scale without supportive political will. Pockets of successful projects will not suffice to build a critical mass of empowered women (and enlightened men) to sustain any positive changes. Winning the support of policy makers is therefore a sinequa-non for empowerment education if the latter is to help promote women's advancement in society

The question is: what types of arguments can one use to gain policy makers's support?

Elson (Depthnews 1992) is doubtful about the wisdom of the prevalent practice of the attempt to fit the women's agenda into the overall development process. She argues that "...although women in development programmes have elements of empowerment, they are based more on the "static" rather than the "dynamic" concept of power."

Miller (1992) asserts that basing arguments on the male/female dichotomy is non-productive. Instead, she proposes that the discussion considers the new term of the "human community".

\section{Suggestion and recommendations}

Fundamental education and skill-based training helps girl child and women by means to addition and alteration of long-term age old, theoretical and hectic men-made imposed systems and requires sensitization and care. A supportive climate must exist to open minds to alternative ways of thinking and make them more receptive to change.

To make and ensure that attitudinal change have to be participatory and non-threatening. A new affective component should provide a setting of safety and tolerance in which participants could intelligently question their own attitudes, values and beliefs.
Work skills alone do not empower women. Productive Programmes for self-reliance have to include confidence building and other survival skills, such as communication, management and problem-solving.

To integrate work skills, developers have to draw on the latest expertise in relevant fields. Accurate and fruitful programmes to be given, trained to girl child and women especially who belongs to rural areas.

Frequently arrange different kinds of training, workshop and courses for grooming of girls and women for enhancing self-esteem and self-confidence.

Numeracy and literacy must be integrated into functional contents in meaningful ways.

Extra-curricular activities fostering group solidarity are as necessary as the technical component. This takes a great deal of planning and active involvement of the group. While women enjoy priority as workshop leaders in this area, male participants with positive background and experience are very helpful in effecting a change in gender aptitudes both in women and men.

\section{Conclusion}

Government of India as well Government of West Bengal launching so many schemes time to time for girls and women in her education like, free schooling, Kannyasree-1, 2 and 3 mid-day meal, free-hostels, cloth, by-cycle, various scholarships, train and bus concession etc. "Expansion of Skills-based Literacy Programme of Women", (An UNDP Project) is mainly for Educate to Empower from the title of the manual it produced. The vital four productive training components such as gender issues, work oriented activities, literacy and numeracy skills and principles of curriculum design are collectively claiming to focus on women empowerment. Finally conclude my papers that women as family, society and community's active members who need functional, proper productive education and training to ensure participation meaningfully, effectively in any sort of work and vice-a-vice partner of men.

\section{Reference}

1. Agrawal S, Salve S. Women Empowerment: Need of Women Education. Indian Journal of Education Research Experimentation and innovation (IJEREI), ISSN-2231-0495. 2013, 3.

2. Alva A, Hans VB. Higher Education in IndiaOpportunities, Changes and Challenges. 2013. Available at http://ssrn.com/abstract=2203706

3. Balve S. Women Entrepreneurship towards women Empowerment in India: Plan Initiatives Southern Economist. 2015;54(3):11-16

4. Sharma P. Role of Education in Women Empowerment. 2016. Available at: http//www.Indianyouthnet/role-ofeducation-in-women-empowerment.

5. Abha Avasthi, Srivastava AK ed. Modernity, Feminism and Women Empowerment, Jaipur and New Delhi: Rawat Publication. 2001, 170-73.

6. Smita Narula, Broken People: Caste Violence against India's Untouchables, United States of America: Human Rights Watch, 1999, 24.

7. Sharma KL. Social Stratification in India: Issues and Themes, New Delhi: Sage Publication. 1997, 16.

8. Thiruchandran Selvy, Ideology Caste, Class and Gender, New Delhi: Vikas Publishing House Pvt. Ltd. 1993, 13. 